\title{
Menisküs Yırtığı Hastalarının Sinoviyal Hücrelerinde Matriks Metalloprotein-2 ve NF-kß Protein Ekspresyonu
}

\author{
Murat Baloğlu${ }^{1}$, Ebru Gökalp Özkorkmaz ${ }^{2 *}$ \\ ${ }^{1}$ Gazi Yaşargil Araştırma Hastanesi Fiziksel Tıp ve Rehabilitasyon Kliniği, Diyarbakır, Türkiye \\ ${ }^{2}$ Dicle Üniversitesi Tıp Fakültesi Histoloji-Embriyoloji ABD, Diyarbakır, Türkiye \\ email:murbal21@hotmail.com, ebrug76@gmail.com \\ Orcid: 0000-0002-3478-1461 \\ Orcid: 0000-0002-1967-4844 \\ *Sorumlu Yazar / Corresponding Author: Sorumlu Yazar: Ebru Gökalp Özkorkmaz
}

\author{
Gönderim Tarihi / Received: 21.01.2019 \\ Kabul Tarihi / Accepted: 03.12.2019 \\ DOI: $10.34087 /$ cbusbed.515563
}

\begin{abstract}
Amaç: Menisküs zorlanmalara karşı emici özelliği ile eklem stabilitesini sağlar. Menisküs yırtığı ise yaşam kalitesini düşüren ciddi bir travmadır. Bu çalışmada, menisküs yırtığı durumunda sinoviyal sıvıdaki hücrelerde meydana gelen farklılıkların immünohistokimyasal yöntemlerle incelenmesi amaçlanmıştır.

Gereç ve Yöntem: Menisküs yırtığı olan 28 erkek ve 32 kadın hasta çalışmaya dahil edilmiştir. Hastaların fizik muayenede lokal ağrı hissi, şişme, günlük aktivitelerini yerine getirmekte ve koşma-yürümede güçlük gibi şikayetleri olduğu belirlendi. Hastaların manyetik rezonans görüntülemeleri (MRG) değerlendirildi. Menisküs ağrısı olan dizlerin yanal suprapatellar poş kısmından enjektör ile 5 cc sinoviyal sıvıları aspire edildi. Örneklerin rutin histolojik takipleri yapıldıktan sonra parafine gömüldü ve mikrotom ile yarı-ince kesitleri alındı. İmmunohistokimyasal analiz için matriks metaloprotein (MMP-2) ve nükleer faktör kappa (NF-k $\beta$ ) primer antikorları kullanıldı. Kesitlerin şık mikroskobu ile fotoğrafları çekildi ve değerlendirildi.

Bulgular: MRG sonucu eklem içerisinde mayi artışı ve parçalı yırtık izlendi. Kadın hastaların eklem sıvılarında lenfosit ve nötrofil hücrelerinde ve hiperplastik eritrositler ile fibroblast sayısında artış gözlendi. Erkek hastalarda, fibroblast hücreleri hiperplastik olarak izlendi ve plazma hücrelerinin arttığ görüldü. MMP-2 ekspresyonunun plazma hücrelerinde, fibroblastlarda ve nötrofillerde arttı̆̆ çekirdeğe sahip hücrelerde pozitif olduğu izlendi.

Sonuçlar: Menisküs yırtığı ve enflamasyonu olan eklemlerde artmış sıvının kıkırdak matriksinde hasara neden olduğu ve buna bağlı olarak MMP-2 ve NF-k $\beta$ gibi sitokinlerin ekspresyonunun arttığı, fibroblast hücreleri gibi sentez yapan hücrelerin yıkıma uğradığı düşünülmektedir.
\end{abstract}

Anahtar Kelimeler: Menisküs Yırtığı, Sinoviyal Hücreler, MMP-2, NF-K $\beta$, İmmunohistokimya.

\footnotetext{
Abstract

Aim: Meniscus provides joint stability with its absorbent properties. Meniscal tear is a serious trauma that reduces the quality of life. In this study, we aimed to investigate the differences in the cells of synovial fluid in case of meniscus tear by immunohistochemical methods.

Materials and Methods: The present study included 28 male and 32 female patients with meniscal tears. Physical examination of the patient revealed local pain, swelling, difficulty in performing daily activities, and walking. Magnetic resonance imaging of the patients were evaluated. The synovial fluids of $5 \mathrm{cc}$ were aspirated by the injector from the lateral suprapatellar pouch portion of the knees with meniscus pain. After routine histological follow-up of the samples, they were embedded in paraffin and semi-thin sections were taken with microtome. Matrix metalloprotein (MMP-2) and nuclear factor kappa (NF-k $\beta$ ) primary antibodies were used for immunohistochemical analysis of the samples. Sections were photographed with light microscope and evaluated.

Results: There was an increase in the number of lymphocytes and neutrophil cells and hyperplastic erythrocytes and fibroblasts in the joint fluids of female patients. In male patients, fibroblast cells were observed to be hyperplastic and plasma cells were increased. MMP-2 expression was increased in plasma cells, fibroblasts and neutrophils besides, NF-k $\beta$ expression was positive in lymphocytes and cells with polymorphic nuclei.

Conclusion: It is believed that increased fluid in the joints with meniscal tear and inflammation caused damage in the cartilage matrix and therefore expressions of cytokines such as MMP-2 and NF-k $\beta$ were increased, and synthesizing cells such as fibroblasts were destroyed.
} 
Keywords: Meniscus Tear, Sinovial Cells, MMP-2, NF-K $\beta$, Immunohistochemistry.

\section{Giriş}

Menisküs, femur ve tibia kemikleri arasında yer alan fibro-kıkırdak benzeri bir dokudur. Așırı zorlanmalara karşı emici özelliği ile eklem stabilitesini sağlama görevi vardır. Şoku emerek yükün iletimi ile diz ekleminin normal fonksiyonunu yerine getirmesini sağlar ve eklemin uzun süre sağlıklı kalabilmesinde önemli bir rol oynar. Menisküs, sinoviyal siv1 kıkırdağını yüzeye doğru iterek eklem yüzeyinde oluşan sinoviyal film tabakasını korumak suretiyle kıkırdağın beslenmesine katkıda bulunurlar [1]. Dizin bükülmesi sırasında menisküsün hareketi eklem yüzeyleri arasındaki sürtünmeyi ortadan kaldırarak oluşabilecek hasarı engeller. Özellikle, mediyal menisküsün posteromediyal kısmı daha hareketsizdir ki bu durum bu bölgede neden daha sık yırtık görüldüğünü açılar [2]. Menisküs yaşla birlikte yıprandıkça, dejeneratif hastalık, travma yada her ikisinden birden kaynaklanan lezyonlara ve yırtıklara daha meyilli hale gelir, bu da ciddi kas iskelet sistemi hastalıklarına yol açar [3].

Genç bireylerde meniküs dokusu sağlamdır ve ancak ciddi travmalar sonucu yırtılabilir. Menisküs yırtığında genellikle sıvı birikimi görülür. Hasta bunu dizde şişlik ve dolgunluk hissi olarak algılar. Menisküs hasarı ve kaybı, menisküs ve eklem dokularında hem biyolojik hem de mekanik lokal yanıtlarla sonuçlanır $[4,5]$.

Normal menisküs yırtıkları, menisküse aşırı yüklenmeden sonra ortaya çıkan travma veya dejeneratif yırtıklar ile sonuçlanan akut yırtıklar olarak ortaya çıkar. Travmatik yırtıklar genellikle 10-40 yaş arası meydana gelmektedir. Dejeneratif yırtıklar ise genellikle 40 yaşın üstündeki kişilerde görülür. $\mathrm{Bu}$ tip yırtıklar genellikle dizin kıkırdak ve kemik dokularındaki diğer dejeneratif değişikliklerle ilişkilidir. Menisküs yırtıkları posttravmatik artrit gelişimi için önemli bir risk faktörüdür ve yaralanma sonrasındaki onarımın 10-20 yılı içinde semptomatik osteoartrit gelişme olasılığını\% 50 artırır [6].

$\mathrm{Bu}$ biyolojik değişiklikler, muhtemel eklem remodelizasyonunu ve hastalık progresyonunu yansitan hücre dışı matriks sentezi ve yıkımını ve enflamasyon süreçlerini ifade eden biyomarkırların ölçülmesiyle belirlenebilir $[4,7]$. Matriks sentezi ve metalloproteinaz (MMP) inhibisyonu arasındaki denge de menisküsün tamiri için çok önemlidir [8]. Sinoviyal sıvıdaki büyüme faktörleri ve MMP'lerin seviyesi, sinoviyal sıvı eklemle ilgili yapılarla doğrudan fiziksel temas halinde olduğu ve hareket sırasında sürtünmeyi azalttı̆ğ için osteoartritin hangi aşamada olduğunu yansitabilir [9]. MMP-2'nin de dahil olduğu kollajen parçalayan MMP'lerin tümü sinoviyum içerisindeki hücrelerde olduğu gibi kondrositler tarafindan üretilir. Sinoviyal sıvida kıkırdak metabolizmasındaki matriks metalloproteinazları da kapsayan bir seri biyomarkırların osteoartirit oluşumu ile ilişkili olduğu bilinmektedir $[10,11,12]$.

Transkripsiyon faktörü nükleer faktör-kB(NF-kB), çeşitli hücrelerde immün cevap, hücre çoğalması ve apopitoz, oksidatif stres, organ gelişimi gibi çok çeşitli hücresel olaylara dahil olan genleri aktive etmektedir $[13,14]$. Genetik farklılıklar, enflamatuvar hastalıklar ve diğer sinyal yolaklarındaki bileşenler NF-kB sinyal yolunda bozulmalara neden olabilmektedir [15].

$\mathrm{Bu}$ çalışmada, enflamatuvar yanıt ve hareketin azalması ile karakterize menisküs yırtığı durumunda sinoviyal sıvıdaki hücrelerde MMP-2 ve NF-k $\beta$ aktivitesini immünhistokimyasal yöntemlerle araştırmak amaçlanmıştır.

\section{Materyal ve Metot}

\section{1 Örneklerin alınması ve hazırlanması}

$\mathrm{Bu}$ araştırmada Diyarbakır Gazi Yaşargil Fizik Tedavi ve Rehabilitasyon Kliniği'ne menisküs yırtığı şikayeti ile başvuran hastalar ile çalışılmıştır. Hastalardan onam formları alınmıştır. Çalışmaya Haziran 2017-Temmuz 2018 tarihleri arasında Fizik Tedavi ve Rehabilitasyon Kliniği'ne lokal ağrı hissi, şişme, merdiven çıkamama ve emeklemede, günlük yaşam aktivitelerini yerine getirmede zorluk, palpasyon ile lokal ağrı, yürüme ve koşma esnasında oluşan şikayetler ile başvuran hastalar dahil edilmiştir.

Menisküs yırtığ 1 olan 28 erkek hastanın (35-58 yaş arası) ve 32 kadın hastanın (32-64 yaş arası) manyetik rezonans görüntüleri (MRG) değerlendirilmiştir.

Hasta yatay pozisyondayken, en az 5 cc sinoviyal sıvı, bir enjektör yardımı ile menisküs ağrısı olan dizlerin lateral suprapatellar poş kısmından aspire edildi.

Sinoviyal sıvı santrifüj edildi ve süpernatan kısmı atıldı ve \% 10'luk nötral formalin solüsyonu 1:3 oranında tüpe eklendi. 2 saatlik fiksasyon aşamasından sonra berrak süpernatan kısmı atıldı. Tüp filtre kağıdı üzerine başaşağı çevirilerek fazla sıvı uzaklaştırıld. Herbir blok için filtre kağıdı, doku kasetleri ve eosin boyama hazırlandı. Çökelti spatula yardımı ile filtre kağıdı üzerine alındı. Eosin boya Pasteur pipet yardımıla çökelti üzerine damlatıldı. Çökelti kırmızı renkli görünüm alınca filtre kağıdı ile beraber kaset içine yerleştirildi ve kaset içerisinde fiksasyon ve doku takibine alındı, parafine gömüldü ve mikrotom ile (Leica, Almanya) yaklaşık 4-5 $\mu \mathrm{m}$ kalınlığında yarı-ince kesitleri alındı.

\subsection{Immünohistokimyasal boyama ve inceleme}

Kesitler distile suya alındı ve fosfat tamponu ile hazırlanmış salin(PBS) solüsyonunda $3 \times 5$ yıkandı. Antijen (Katalog no 10010023, Thermo Fisher Scientific,USA) retrieval mikrodalgada $3 \mathrm{dk}, 90^{\circ} \mathrm{C}$ de yapıldı (Bosch $®, 700$ watt). Kesitler proteoliz için sitrat tampon solüsyonu içinde $(\mathrm{pH} 6)$, mikrodalgada (700 watt) 1sıtma işlemine tabi tutuldular. Kesitler 3x5 MMP- 
2 kez PBS ile yıkandı ve hidrojen peroksit [K-40677109 ,64271 Hydrogen peroxide $\left(\mathrm{H}_{2} \mathrm{O}_{2}\right)$ MERCK, Almanya] ile $20 \mathrm{dk}$ inkübe edildiler. Kesitler yine $3 \times 5 \mathrm{kez}$ PBS ile y1kand1 ve 8 dk Ultra V Block (lot: PHL150128, Thermo Fisher, USA) ile muamele edildi. Süzüldükten sonra, primer antikorlar MMP-2 (Matrix Metalloprotein-2 monoclonal antibody 1:100, Cat\#PA116667Thermo Fisher, USA) ve NF-k $\beta$ (Cat \# 44-711G Thermo Fisher, USA) direkt olarak kesitlere uyguland1. Kesitler bir gece $+4^{\circ} \mathrm{C}$ 'de bekletildi.

Kesitler 3x5 dk PBS ile y1kandıktan sonra Biotin işaretli sekonder antikor (lot: PHL150128, Thermo Fischer, USA) ile14 dk inkübe edildi. PBS ile yıkandıktan sonra $15 \mathrm{dk}$ Streptavidin Peroksidaz (lot: PHL150128, Thermo Fischer, USA) ile muamele edildi. Tekrar 3x5 kez PBS ile yıkanan kesitlere 10 dk DAB (lot: HD36221, Thermo Fischer, USA) uyguland1. Reaksiyon görülen lamlar PBS ile yıkandı. Zit boyaması $45 \mathrm{dk}$ Harris's Haematoxylin (Product \# HHS32 SIGMA, Hematoxylin Solution, Harris Modified, Sigma-Aldrich, USA) ile gerçekleştirildi, yükselen derecelerdeki alkol ile dehidrate edildikten sonra ksilen ile şeffaflandırması yapild1. Lamlar Entellan ${ }^{\circledR}($ lot no 107961, SigmaAldrich, USA) ile kapatıldı ve Zeiss Imager A2 (Almanya) 1şık mikroskobu ile incelendi.

\section{Bulgular ve Tartışma \\ 3.1 Bulgular}

Hastalar klinik olarak ağrı, sabahları tutukluk, hareket kısıtlılığı, eklemde fonksiyon kaybı ve şişlik ile gelmişlerdi. Başlıca şikayetleri ağrının hareketle artması, istirahatle azalması ve sabah tutukluğuydu. Fiziki muayenede eklemlerde deformite izlendi. Hastaların dizlerinde güç kaybı vardı, merdiven inip çıkmada güçlük çekiyorlardı ve ağrıları mevcuttu.

\subsubsection{MRG bulguları}

Menisküs yırtığı olan hastanın sağ diz MR görüntülemesi sonucu, medial menisküs posterior hornu normal konfügrasyonunu kaybetmiş olup parçalı yırtık ile uyumlu görünüm izlenmiştir. $\mathrm{Bu}$ hastada diz eklemini oluşturan kemik yapılarda yaygın dejeneratif osteoartritik değişiklikler mevcuttu ve eklem aralığında medialde daha belirgin olmak üzere daralma gözlendi. Eklem içerisinde ve suprapatellar bursada belirgin mayi artışı izlendi. Aynı hastanın sol diz MR incelemesinde lateral menisküs anterior hornundan posterior hornuna devam eden parçalı yırtık ile uyumlu görünüm izlenmiştir ve medial meniscus posterior hornunda parçalı yırtık mevcuttu. Eklem içerisinde mayi artışı izlendi (Şekil $1 \mathrm{a}, \mathrm{b})$.

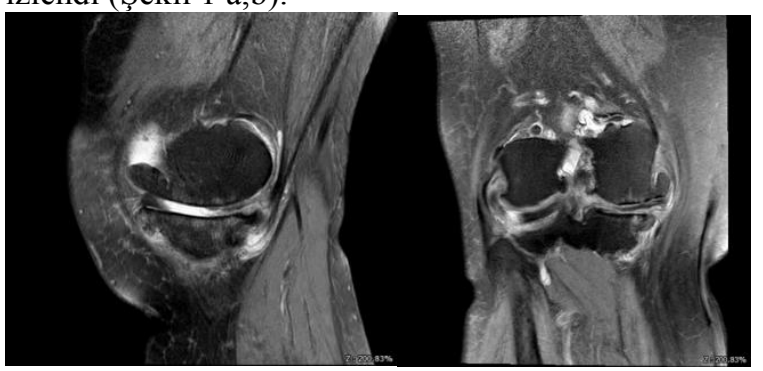

Şekil 1 a, b: Menisküs yırtığı şüphesi olan hastada MR görüntülemesi, medial menisküs posterior hornunda normal konfügrasyon kaybı ve parçalı yırtık izlenmektedir. Lateral menisküs anterior hornundan posterior hornuna devam eden horizontal yerleşimli yırtık izlenmektedir.

\subsection{1 İmmunohistokimya analizi}

Menisküs yırtığı olan kadın hastadan alınan sinoviyal sıvı örneğinde sinoviyal hücrelerin bazılarında, nötrofil ve makrofaj hücrelerinde NFk- $\beta$ ekspresyonunun pozitif olduğu gözlendi. Sinoviyal hücre dağılımının bazı alanlarda soliter bazı alanlarda agregat oluşturduğu, sinoviyal hücrelerin enflamatuvar alanlarında NFk- $\beta$ ekspresyonunun pozitif reaksiyon verdiği görülmüştür.

Menisküs yırtığı olan erkek hastadan alınan sinoviyal siv1 örneğinde sinoviyal hücrelerin gruplaşma gösterdiği, aralarında lokositer hücrelerinde yoğunlukta olduğu, NFk- $\beta$ ekspresyonunun pozitif olduğu görüldü. Proenflamatuvar reaksiyonun tetiklenmesi ile birlikte enflamasyonun arttığı ve bu sinyal yolağ hücrede apoptozisin de indüklendiği görülmüştür.

Menisküs yırtığı olan kadın hastadan alınan sinoviyal sıvı örneğinde ekstrasellüler matriks alanlarında MMP-2 ekspresyonu pozitif olarak belirlenirken polimorf nukleuslu hücrelerde ve fibroblast hücrelerinde MMP-2 pozitif ekspresyonu görüldü. Menisküs yırtığı olan erkek hastaların sinoviyal sıvılarında ekstrasellüler matriks bölgesinde MMP-2 ekspresyonunun arttı̆g1, fibroblast hücrelerinde yoğun MMP-2 ekspresyonunun olduğu görüldü.

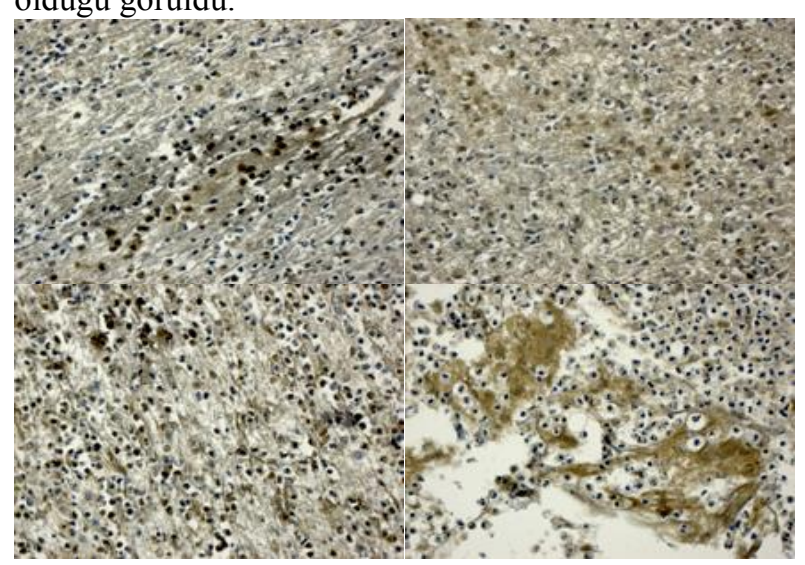

Resim 2a-Menisküs yırtığı olan kadın hastadaki sinoviyal sıvı: Sinoviyal hücre, nötrofil ve makrofaj hücrelerinde NF-k $\beta$ pozitif ekspresyonu NF-k $\beta$ immunboyama, bar $100 \mu \mathrm{m}$ 2b-Menisküs yırtığı olan erkek hastadaki sinoviyal sıvı: Sinoviyal hücrelerin gruplaşma gösterdiği aralarında lokositer hücrelerinde yoğunlukta olduğu NF-k $\beta$ pozitif ekspresyonu, NF-k $\beta$ immun-boyama, bar $100 \mu \mathrm{m}$ 2c-Menisküs yırtığı olan kadın hastadaki sinoviyal sıvı: Ekstrasellüler matriks alanlarında polimorf nukleuslu hücrelerde ve fibroblast hücrelerinde MMP-2 pozitif ekspresyonu, MMP-2 immun-boyama, bar $100 \mu \mathrm{m}$, 2d-Menisküs yırtığı olan erkek hastadaki sinoviyal sıvı: Ekstrasellüler matriks bölgesinde MMP-2, fibroblast ve plazma hücrelerinde 
yoğun MMP-2 ekspresyonu MMP-2 immun-boyama, bar $100 \mu \mathrm{m}$

\subsection{Tartışma}

Menisküs yırtıkları travmatik, dejeneratif veya konjenital patolojiler sonucu oluşurlar [16]. Menisküs yırtıklarına manyetik rezonans görüntüleme ile büyük ölçüde tanı koyulabilir ve MRG sonuçları hastanın klinik bulgularıyla beraber göz önüne alınmalıdır [17]. Çalışmamızda, hastaların MRG incelemeleri (Şekil 1 a, b) menisküs yırtıklarıyla beraber eklem içerisinde ve suprapatellar bursada belirgin mayi artışı olduğunu ortaya koymuştur.

Menisküs hasarının, uzun vadede diz ekleminde osteoartrit gelişimi riskini artırdığı bildirilmiştir [18]. MRG ile yapılan bir çalışmada, osteoartrit hastalarında diz ağrısının kartilaj defektinden ziyade kemik iliği lezyonları ve effüzyon ya da sinovit ile ilişkili olduğu bulunmuştur [19]. Çalışmamızda hastaların MRG sonuçları menisküs bütünlüğündeki bozulma, kıkırdak dejenerasyonu, eklem içerisinde ve suprapatellar kısımdaki belirgin sıvı artışının eklem bütünlüğünün bozulmasına neden olduğu fikrini vermiştir. Soran ve arkadaşları eklem mesafesinde daralma, osteofit varlığı, subkondral erozyon ve sklerozun osteoartritte klasik radyolojik bulgulardan olduğunu, diz osteoatritindeki radyolojik bulguların da eklem mesafesindeki daralmanın, diz ekleminde ağrı ve fonksiyonel yetersizlikle doğrudan bağlantılı olmadığını bildirmişlerdir [20]. Kemik, kıkırdak, eklem yapısını bir bütün olarak kabul ettiğimizde herhangi birinde meydana gelebilecek dejenerasyonun diz ekleminde ağriya ve disfonksiyona ve ileriki safhalarda osteoartrite yol açabileceği düşünülebilir. $\mathrm{Bu}$ nedenle, menisküs yırtığı üzerine yaptığımız bu çalışmanın ileride oluşabilecek osteoartrit durumunun önlenmesi anlamında direkt olmasa da dolaylı yoldan faydası olabileceği düşüncesindeyiz.

Akut enflamasyon genellikle ani bir başlangıç gösterir; 1S1, ağrı, kızarıklık ve şişlik gibi klasik belirtilerle dakikalar veya saatler içerisinde görünür hale gelir. Kronik enflamasyonsa uzun bir süre içinde gelişir ve günler, haftalar veya aylarca sürebilir. Nötrofiller, akut sinovitte en fazla bulunan enflamatuvar hücrelerken osteoartrite bağlı kronik sinovitte sıklıkla lenfositik infiltratlarla birlikte makrofajlar fazla miktarda bulunur [21].

Özellikle dejeneratif menisküs yırtıklarında, ve travmatik menisküs yırtıklarından sonra, menisküs hasarı ve kronik inflamasyon görülür. Çalışmamızda kadın ve erkek hastaların sinoviyal sıvılarında, osteoartrit gelişimi fikrini veren sinoviyal hücre, nötrofiller ve makrofaj hücrelerindeki NFk- $\beta$ ekspresyonunun belirgin olmasıdır. Proenflamatuvar reaksiyonun işareti sayılan bu sinyal yolağının sitokin aktivitesini tetiklediği ve apoptotik değişimleri hızlandırdığı düşünülmüştür (Resim 2 a, b). Enflamatuvar yanıt genellikle ön çapraz bă̆ (anterior cruciate ligament-ACL) rüptürü, travmatik menisküs yırtılması ve erken OA ile ortaya çıkar [22]. Obezite, diurnal ritim, diyet, ilaçlar, örneklerin toplanmasaklanma zamanı ve durumu, aktivite seviyesi, travma, cinsiyet gibi birçok değişken bu hastalarda sitokin seviyelerini etkileyebilmektedir [23, 24]. Artmış sistemik enflamasyon yaşlanma ile doğrudan ilişkilidir.

Yaşlanma, mitokondriyal disfonksiyona ve kondrositlerde oksidatif hasara maruz kalmış proteinlerin ortadan kaldırılmasında yetersizliğe yol açabilir. Bu olay, hücre yaşlanmasını ve enflamatuvar sitokinlerin üretiminde artışı tetikleyebilir [25, 26]. Normal menisküs hücrelerinin uyarıcılara osteoartritik menisküs hücrelerine göre daha hızlı yanıt verdiği bildirilmiştir. $\mathrm{Bu}$ durum, stimülasyondan 6 saat sonra, osteoartritik hücrelere kiyasla MMP ekspresyonunda belirgin bir artış ile kanıtlanmıştır. Bu fark, osteoartritik hücrelerdeki reseptör konsantrasyonundaki veya enflamatuvar yollardaki değişikliklerle ilgili olabilir [27]. MMP'ler, hücre dişı matriksi, bazal membranın da dahil olduğu diğer birçok bileşeni bozunmaya uğratır. $\mathrm{Bu}$ nedenle, tümör yayılımı ve anjiyogenez için önemli olduğu düşünülmektedir [28, 29]. Hücre diş1 matriks, hücre davranışını düzenleyici özelliğin yanı sıra hücre ve dokulara dinamik destek sağlayan yapısal ve sinyal moleküllerinin karmaşık bir ağıdır [30,31]. Matriks metalloproteinazlar, hücre dışı matriks degradasyonunu, bozunmasını başlatarak patolojik süreçler sırasında dokunun yeniden biçimlenmesinde önemli bir rol oynayan proteolitik enzimlerdir.

Çalışmamızdan elde edilen sonuçlara göre, hem erkek hem de kadın hastalarda, fibroblast ve polimorf nukleuslu hücrelerde artmış olan MMP-2 ekspresyonunun (Resim 1 c, d) matriks yapısının bozulmasina neden olabilecek kronik bir enflamasyona yol açtığ 1 ve fibroblast hücrelerindeki MMP-2 ekspresyonunun kollajen liflerin sentezini etkileyebileceği düşünülmüştür.

Liu ve ark. (2017) menisküs yırtığı olan hastaların sinoviyal sıvıları üzerine yaptıkları çalışmada, matriks metalloproteinaz aktivitesi ve prostaglandin E2 (PGE2) seviyelerini çalışmışlardır. Sinoviyal sıvı total matriks metalloproteinaz aktivitesinin yani MMP-2 ve MMP3'ün menisküs yırtığ 1 olan hastalarda kontrollere göre 25 kat arttığını bildirmişlerdir. Liu ve ark. MMP ve PGE2'nin y1kıc1 ve pro-enflamatuvar rolleri göz önüne alındığında bu moleküllerin, eklemin biyokimyasal yapısını değiştirebildiğini, menisküs yaralanmaları sonrasında MMP aktivitesinin düzenlenmesinin menisküs onarımını teşvik ederek, OA gelişimini önleyebileceğini bildirmişlerdir [32].

NF-kB; hücrenin yaşamını devam ettirmesi, çoğalma, farklılaşma, apopitoz, yaşlanma, enflamasyon ve immün cevap gibi birçok hücresel süreçte rol oynamaktadır [33]. Bunun yanı sira NF-kB, sitokinleri ve adezyon moleküllerini kodlayan birçok genin aktivitesinin 
düzenlenmesini sağlamaktadır [34]. Saito ve Tanaka (2017) yaptıkları çalışmada NF-kB sinyal yolunun kondrositlerde homeostazı sağladığı ve osteoartrit gelişiminde rol oynadığını belirtmişlerdir [35]. Çalışmamızda, menisküs yırtığı olan kadın hastadan alınan sinoviyal sıvıda sinoviyal hücre, nötrofil ve makrofaj hücrelerinde NF-k $\beta$ pozitif ekspresyonu izlenmiştir. Ayrıca, erkek hastadan alınan sinoviyal sıvıda ise, sinoviyal hücrelerin gruplaşma gösterdiği, aralarında lokositer hücrelerin de yoğunlukta olduğu ve NF-k $\beta$ pozitif ekspresyonu izlenmiştir.

\section{Sonuç}

Çalışmamızda menisküs yırtığı olan hastaların sinoviyal sıvı hücrelerinde MMP aktivitesinin artması, matriks degradasyonuna ve kıkırdak gerginliği oluştuğuna işaret edebilir. Elde edilen sonuçlara göre; menisküs yırtığının sinoviyal hücrelerin k1kırdak matriksini ve k1kırdak gerginliğini etkileyebildiği, matriksi bozunmaya uğratan enzimleri indüklediği düşünülmektedir. Menisküs yırtığ olan eklemlerde artmış sıvı miktarı ve enflamasyon kıkırdak matriksinde bozunmaya ve apoptotik hücre gelişimine neden olmuştur diyebiliriz.

\section{Kaynaklar}

1. Gray, J.C. Neural and vascular anatomy of the menisci of the human knee. Journal of orthopaedic and sports physical therapy, 1999, 29(1),23-30.

2. Kurosawa, H, Fukubayashi, T,Nakajima, H, Load-bearing mode of the knee joint: physical behavior of the knee joint with or without menisci. Clinical Orthopaedics and Related Research, 1980, 283-290.

3. Fox, A.J, Wanivenhaus, F, Burge, A.J, Warren, R.F, Rodeo, S.A, The human meniscus: a review of anatomy, function, injury, and advances in treatment. Clinical Anatomy, 2015, 28, 269-287.

4. Koryem, H.K, Wanas, M, Rizk, M.M.A, Kotb, H.T, Naguib, A.H, Shafei, M.M.A.H.E, Naby, H.M.A.A.E. Evaluation of early changes of cartilage biomarkers following arthroscopic meniscectomy in young egyptian adults. Alexandria Journal of Medicine, 2015,51(3),191-197.

5. McNulty, A.L, Rothfusz, N.E, Leddy, H.A, Guilak, F. Synovial fluid concentrations and relative potency of interleukin-1 alpha and beta in cartilage and meniscus degradation. Journal of Orthopaedic Research, 2013, 31(7),1039-1045

6. Lohmander, L.S, Englund, P.M, Dahl, L.L, The long-term consequence of anterior cruciate ligament and meniscus injuries: osteoarthritis. American Journal of Sports Medicine, 2007, 35, 1756-1769.

7. Lotz, M, MartelPelletier, J, Christiansen, C, Brandi, M.L, Bruyere, O, Chapurlat, R, Collette, J, Cooper, C, Giacovelli, G, Kanis, J.A, Karsdal, M.A, Kraus, V, Lems W.F, Meulenbelt, I, Pelletier, JP, Raynauld, J.P, Reiter-Niesert, S, Rizzoli, R, Sandell, L.J, Van Spil, W.E, Reginster, J.Y. Value of biomarkers in osteoarthritis: current status and perspectives. Annals of the Rheumatic Diseases, 2013,72(11),1756-1763.

8. Buma, P, Ramrattan, N.N, van Tienen, T.G, Veth, R.P.H, Tissue engineering of the meniscus. Biomaterials, 2004, 25, 1523-1532.

9. Balakrishnan, L, Nirujogi, R.S, Ahmad, S, Bhattacharjee, M, Manda, S.S, Renuse, S, Kelkar, D.S, Subbannayya, Y, Raju, R, Goel R, Proteomic analysis of human osteoarthritis synovial fluid. Clinical Proteomics, 2014,11, 6.

10 Baragi, V.M, Becher, G, Bendele, A.M, Biesinger, R, Bluhm, $\mathrm{H}$, Boer, J, Deng, H, A new class of potent matrix metalloproteinase 13 inhibitors for potential treatment of osteoarthritis: Evidence of histologic and clinical efficacy without musculoskeletal toxicity in rat models. Arthritis \& Rheumatology, 2009, 60(7), 2008-18.

11. Janusz, M.J, Bendele, A.M, Brown, K.K, Taiwo, Y.O, Hsieh, L, Heitmeyer, S.A, Induction of osteoarthritis in the rat by surgical tear of the meniscus: Inhibition of joint damage by a matrix metalloproteinase inhibitor. Osteoarthritis Cartilage, 2002,10, 785-91.

12. Pozgan, U, Caglic, D, Rozman, B, Nagase, H, Turk, V, Turk, $\mathrm{B}$, Expression and activity profiling of selected cysteine cathepsins and matrix metalloproteinases in synovial fluids from patients with rheumatoid arthritis and osteoarthritis, Biological Chemistry, 2010, 391(5), 571-9.

13. Hayden, MS, Ghosh, S, Signaling to NF-kappaB, Genes \& Development, 2004, 18, 2195-2224.

14. Mitchell, S, Vargas, J, Hoffmann, A, Signaling via the NFkBsystem. Wiley Interdisciplinary Reviews Systems Biology and Medicine, 2016, 8, 227-241.

15. Wong, E.T, Tergaonkar, V, Roles of NF- $\mathrm{kB}$ in health and disease: mechanisms and therapeutic potential. Clinical Science 2009,116(6), 451-465.

16. Alparslan B, Çullu E. Menisküs yaralanmaları ve cerrahi tedavileri. ADÜ Tıp Fakültesi Dergisi, 2000, 1, 47-55.

17. Özer H, Yıldırım A, Menisküs lezyonlarında görüntüleme. OTBID Dergisi, 2018, 17,114-122. https://doi.org/10.14292/totbid.dergisi.2018.14

18. Auth PC, Orthopedics. In: Ballweg R, Sullivan E, Brown D, Vetrosky D Physician Assistant A Guide to Clinical Practice, 4th edn. Saunders, New York, 2008, pp 474-491.

19. Yusuf E, Kortekaas MC, Watt I, Huizingia TW, Do knee abnormalities visualized on MRI explain knee pain in knee osteoarthritis? A systematic rewiew. Ann Rheum Dis 2011;70:60-7.

20. Soran N, Altındağ Ö, Demirkol A, Tabur H, Diz Osteoartritinde Radyolojik Bulgular ve Klinik Parametrelerle iliskisi. Türk Fiz Tıp Rehab Derg 2008, 54, 59-62.

21. Lingen, M.W, Role of leukocytes and endothelial cells in the development of angiogenesis in inflammation and wound healing. Archives of Pathology \& Laboratory Medicine 2001, $125,67-71$

22. Englund, M. A, Guermazi, S, Lohmander, L, The role of the meniscus in knee osteoarthritis: a cause or consequence? Radiologic Clinics of North America 2009, 47, 703-712.

23. Payette, C. P, Blackburn, B. Lamarche, et al. Sex differences in postprandial plasma tumor necrosis factor-alpha, interleukin-6, and C-reactive protein concentrations. Metabolism, 2009,58,1593-1601

24. Zhou, X, Conceptual and methodological issues relevant to cytokine and inflammatory marker measurements in clinica research. Current Opinion in Clinical Nutrition and Metabolic Care, 2010, 13, 541-547.

25. Berenbaum, F, Osteoarthritis as an inflammatory disease. Osteoarthritis and Cartilage, 2013,21,16-21.

26. Loeser, R.F, The effects of aging on the development of osteoarthritis. Hospital for Special Surgery, 2012, 18-19.

27. Stone, A.V, Loeser R.F., Vanderman K.S.,. LongD.L, Clark S.C., Ferguson C.M. Pro-inflammatory stimulation of meniscus cells increases production of matrix metalloproteinases and additional catabolic factors involved in osteoarthritis pathogenesis. Osteoarthritis and Cartilage, 2014, $264 \mathrm{e} 274$.

28. Nagase, H, Woessner, J.F.J, Matrix metalloproteinases, Journal of Biological Chemistry, 1999, 274, 21491-21494.

29. Overall, C.M, Molecular determinants of metalloproteinase substrate specificity: matrix metalloproteinase substrate binding domains, modules, and exosites. Molecular Biotechnology, 2002,22, 51-86.

30. Mott, J.D, Werb, Z, Regulation of matrix biology by matrix metalloproteinases. Current Opinion in Cell Biology, 2004, 16, 558-564

31. Page-McCaw A, EwaldA.J., Werb, Z. Matrix metalloproteinases and the regulation of tissue remodelling. Nature Reviews Molecular Cell Biology, 2007,8, 221-233.

32. Liu, B, Goode, A.P, Carter, T.E, Utturkar, G.M, Huebner, J.L, Taylor, D.C, Matrix Metalloproteinase Activity and 
Prostaglandin E2 are Elevated in the Synovial Fluid of Meniscus Tear Patients, Connective Tissue Research, 2017,58(3-4),305-316.

33. Bonizzi, G, Karin, M, The two NF-kappaB activation pathways and their role in innate and adaptive immunity, Trends in Immunology, 2004, 25(6),280-288.

34. Wang, T, Zhang, X, Li, J, The role of NF-nB in the regulation of cell stress responses. International Immunopharmacology, 2002, 1509-1520.

35. Saito, T, Tanaka, S, Molecular mechanisms underlyingosteoarthritis development: Notch and NF- $\kappa$ B Arthritis Research \& Therapy,2017, 19,94.

http://edergi.cbu.edu.tr/ojs/index.php/cbusbed isimli yazarın CBU-SBED başlıklı eseri bu Creative Commons AlıntıGayriticari4.0 Uluslararası Lisansı ile lisanslanmıştır.

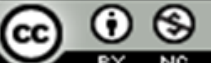

